\title{
Influence of reheat pressure on reheat cycle economy
}

\author{
YarongWang ${ }^{1, *}$, and PeirongWang ${ }^{2}$ \\ ${ }^{1}$ Baoding Electric Power VOC.\&TECH. College, Baoding, Hebei, 071051, China \\ ${ }^{2}$ Hebei Software Institute, Baoding, Hebei, 071000, China
}

\begin{abstract}
After steam expands to a certain intermediate pressure in steam turbine, it is led out of steam turbine and sent to reheater of boiler. The steam is heated to the initial temperature by constant pressure in the reheater. After that, the steam is introduced into the steam turbine and continues to expand to the exhaust steam pressure. The steam after work enters the condenser for cooling and heat release. Such a steam power cycle is a reheat cycle. The purpose of reheat cycle is to solve the contradiction that the dryness of exhaust steam decreases after the application of high parameters in steam power cycle. Through theoretical study and qualitative analysis, we know that the correct selection of reheat pressure can not only improve the steam turbine exhaust dryness, but also improve the thermal efficiency of the cycle. Reheat pressure is very important to the economy of reheat cycle and the safe operation of equipment. The correct choice of reheat pressure will affect the economy of the whole cycle.
\end{abstract}

\section{Introduction}

The unit system of reheat cycle is shown in Figure 1 [1]. The steam enters the high pressure cylinder of the steam turbine and expands to do work to a certain intermediate pressure. Then it is led out of the steam turbine and sent to reheater of the boiler. The steam is heated to the initial temperature by constant pressure in the reheater. After that, the steam is introduced into the steam turbine and continues to expand to the exhaust steam pressure. The steam after work enters the condenser for cooling and heat release. This is the basic process of reheat cycle. The T-s diagram of reheat cycle is shown in Figure 2 [2].

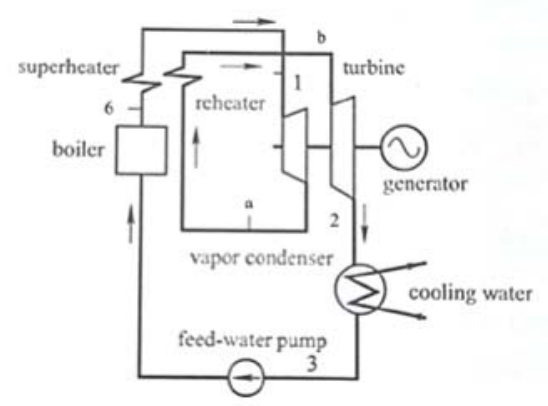

Fig. 1. Unit system diagram of reheat cycle.

The purpose of reheat cycle is to solve the contradiction that the dryness of exhaust steam decreases after the application of high parameters in steam power cycle. After using the intermediate reheat, the exhaust dryness of the steam turbine can be improved, and the steam dryness in the low pressure cylinder can be kept within a normal working range, so as to enhance the safety of the steam turbine and avoid the adverse effects caused by increasing the initial pressure of the steam.

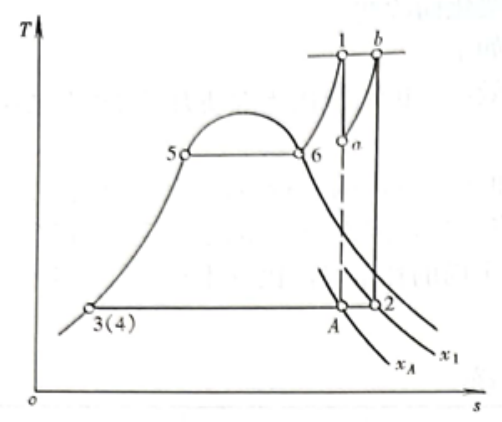

Fig. 2. T-s diagram of reheat cycle.

Through theoretical study and qualitative analysis, we know that the correct selection of reheat pressure can not only improve the steam turbine exhaust dryness, but also improve the thermal efficiency of the cycle. Generally, the reheat pressure should be $20 \% \sim 30 \%$ of the initial pressure. Here we take an example to calculate the thermal efficiency, steam consumption rate and exhaust dryness under different conditions by selecting three different reheat pressures. For the teaching of our vocational colleges, this kind of comparative calculation can not only consolidate the theoretical knowledge, strengthen the qualitative analysis, but also enhance the perceptual knowledge.

\section{Analysis of Reheat cycle with different reheat pressure}

Let us analyze Reheat cycle through an example.

\footnotetext{
*Corresponding author: bjoycg2008@163.com
} 
Example:

A steam turbine generator unit works according to reheat cycle. The initial parameters of steam are $\mathrm{p}_{1}=10.0 \mathrm{MPa}, \mathrm{t}_{1}=540^{\circ} \mathrm{C}$. The reheat pressure is $\mathrm{p}_{\mathrm{a}}=3 \mathrm{MPa}$. The reheat temperature is $t_{b}=540^{\circ} \mathrm{C}$. The final pressures is $\mathrm{p}_{2}=0.004 \mathrm{MPa}$. Try to calculate the thermal efficiency, steam consumption rate and exhaust dryness of the reheat cycle. If reheat is not used, what are the heat efficiency, steam consumption rate and exhaust dryness of Rankine cycle with the same parameters [2]?

In order to strengthen the comparison, we further select the reheat pressure of $1 \mathrm{MPa}$ and $7 \mathrm{MPa}$ for calculation.

Solution:

According to the known initial temperature, initial pressure, reheat pressure and exhaust pressure, the state parameters of relevant state points are obtained on the hs diagram. The h-s diagram is shown in Figure 3 [2].

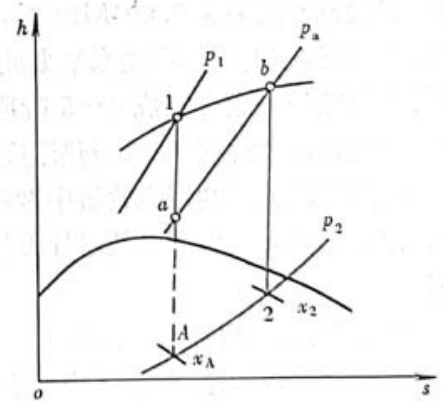

Fig. 3. H-s diagram of reheat cycle.

Look up the h-s diagram, and we get the following results:

$$
\begin{array}{ll}
h_{1}=3475 & \mathrm{~kJ} / \mathrm{kg} \\
h_{a}=3105 & \mathrm{~kJ} / \mathrm{kg} \\
h_{A}=2025 & \mathrm{~kJ} / \mathrm{kg} \\
h_{b}=3547 & \mathrm{~kJ} / \mathrm{kg} \\
t_{s 2}=29 & { }^{\circ} \mathrm{C} \\
h_{2}=2205 & \mathrm{~kJ} / \mathrm{kg} \\
x_{A}=0.783 & \\
x_{2}=0.858 &
\end{array}
$$

According to the calculation formulas of reheat cycle thermal efficiency and steam consumption rate, the results are as follows

$$
\begin{aligned}
\eta_{t} & =\frac{\left(h_{1}-h_{a}\right)+\left(h_{b}-h_{2}\right)}{\left(h_{1}-h_{2}^{\prime}\right)+\left(h_{b}-h_{a}\right)} \\
& =\frac{(3475-3105)+(3547-2205)}{(3475-121.42)+(3547-3105)}=45.12 \%
\end{aligned}
$$

here

$$
\begin{aligned}
h_{2}^{\prime} & \approx 4.1868 \times t_{s 2} \\
& =4.1868 \times 29=121.42 \quad \mathrm{~kJ} / \mathrm{kg} \\
d & =\frac{3600}{\left(h_{1}-h_{a}\right)+\left(h_{b}-h_{2}\right)} \\
& =\frac{3600}{(3475-3105)+(3547-2205)} \\
& =2.10 \mathrm{~kg} /(\mathrm{kw} \cdot \mathrm{h})
\end{aligned}
$$

For the convenience of comparison, we choose two different reheat pressures to calculate.

When the reheat pressure is $1 \mathrm{MPa}$, the same method is used to check the relevant parameters and calculate the thermal efficiency and steam consumption rate.

$$
\begin{aligned}
h_{1} & =3475 \quad \mathrm{~kJ} / \mathrm{kg} \\
h_{a} & =2842 \quad \mathrm{~kJ} / \mathrm{kg} \\
h_{b} & =3540 \quad \mathrm{~kJ} / \mathrm{kg} \\
h_{2} & =2373 \quad \mathrm{~kJ} / \mathrm{kg} \\
x_{2} & =0.925 \\
\eta_{t}= & \frac{\left(h_{1}-h_{a}\right)+\left(h_{b}-h_{2}\right)}{\left(h_{1}-h_{2}^{\prime}\right)+\left(h_{b}-h_{a}\right)} \\
& =\frac{(3475-2842)+(3540-2373)}{(3475-121.42)+(3540-2842)}=44.43 \% \\
d & =\frac{3600}{\left(h_{1}-h_{a}\right)+\left(h_{b}-h_{2}\right)} \\
& =\frac{3600}{(3475-2842)+(3540-2373)} \\
& =2.00 \quad \mathrm{~kg} /(\mathrm{kw} \cdot \mathrm{h})
\end{aligned}
$$

Similarly, when the reheat pressure is $7 \mathrm{MPa}$.

$$
\begin{aligned}
h_{1} & =3475 \quad \mathrm{~kJ} / \mathrm{kg} \\
h_{a} & =3355 \quad \mathrm{~kJ} / \mathrm{kg} \\
h_{b} & =3507 \quad \mathrm{~kJ} / \mathrm{kg} \\
h_{2} & =2080 \quad \mathrm{~kJ} / \mathrm{kg} \\
x_{2} & =0.807 \\
\eta_{t} & =\frac{\left(h_{1}-h_{a}\right)+\left(h_{b}-h_{2}\right)}{\left(h_{1}-h_{2}^{\prime}\right)+\left(h_{b}-h_{a}\right)} \\
& =\frac{(3475-3355)+(3507-2080)}{(3475-121.42)+(3507-3355)}=44.13 \% \\
d & =\frac{3600}{\left(h_{1}-h_{a}\right)+\left(h_{b}-h_{2}\right)} \\
& =\frac{3600}{(3475-3355)+(3507-2080)} \\
& =2.33 \quad \mathrm{~kg} /(\mathrm{kw} \cdot \mathrm{h})
\end{aligned}
$$

Under the same initial and final parameters, the calculation of Rankine cycle is as follows. 


$$
\begin{aligned}
\eta_{t} & =\frac{h_{1}-h_{A}}{h_{1}-h_{2}^{\prime}} \\
& =\frac{3475-2025}{3475-121.42}=43.24 \% \\
d & =\frac{3600}{h_{1}-h_{A}} \\
& =\frac{3600}{3475-2025}=2.48 \quad \mathrm{~kg} /(\mathrm{kw} \cdot \mathrm{h})
\end{aligned}
$$

The calculation results of several different cases are summarized in Table 1.

Table 1. Summary of calculation results in different situations

\begin{tabular}{|c|c|c|c|c|}
\hline & $\begin{array}{c}\text { Rankine } \\
\text { cycle }\end{array}$ & \multicolumn{3}{|c|}{ Reheat cycle } \\
\hline $\begin{array}{c}\text { Initial } \\
\text { pressure }\end{array}$ & $10 \mathrm{MPa}$ & $10 \mathrm{MPa}$ & $10 \mathrm{MPa}$ & $10 \mathrm{MPa}$ \\
\hline $\begin{array}{c}\text { Initial } \\
\text { temperature }\end{array}$ & $540^{\circ} \mathrm{C}$ & $540^{\circ} \mathrm{C}$ & $540^{\circ} \mathrm{C}$ & $540^{\circ} \mathrm{C}$ \\
\hline Final pressure & $0.004 \mathrm{MPa}$ & $0.004 \mathrm{MPa}$ & $0.004 \mathrm{MPa}$ & $0.004 \mathrm{MPa}$ \\
\hline $\begin{array}{c}\text { Reheat } \\
\text { pressure }\end{array}$ & - & $1 \mathrm{MPa}$ & $3 \mathrm{MPa}$ & $7 \mathrm{MPa}$ \\
\hline $\begin{array}{c}\text { thermal } \\
\text { efficiency }\end{array}$ & 43.24 & 44.43 & 45.12 & 44.13 \\
\hline $\begin{array}{c}\text { Steam } \\
\text { consumption } \\
\text { rate }\end{array}$ & 2.48 & 2.00 & 2.10 & 2.33 \\
\hline $\begin{array}{c}\text { Exhaust steam } \\
\text { dryness }\end{array}$ & 0.783 & 0.925 & 0.858 & 0.807 \\
\hline
\end{tabular}

Above we use h-s diagram for analysis and calculation. In addition, using the thermodynamic property table of steam to analyze, the calculation results are more accurate, but the calculation process is more complicated. Take the reheat pressure of $3 \mathrm{Mpa}$ as an example, let's use the thermodynamic property table of steam to analyze the problem.

Table 2. Properties of unsaturated water and superheated vapor (by pressure and temperature)

\begin{tabular}{|c|c|c|c|}
\hline \multirow{2}{*}{$p$} & \multicolumn{3}{|c|}{$3.0 \mathrm{MPa}$} \\
\hline \multirow{3}{*}{$\begin{array}{c}\text { Sat } \\
\text { properties }=233.893^{\circ} \mathrm{C}\end{array}$} & \multicolumn{3}{|c|}{$\mathrm{v}^{\prime}=0.0012166 \mathrm{v}^{\prime \prime}=0.066700$} \\
$\mathrm{~h}^{\prime}=1008.2 \mathrm{~h}^{\prime \prime}=2803.2$ \\
$\mathrm{~s}^{\prime}=2.6454 \mathrm{~s}^{\prime \prime}=6.1854$ \\
\hline $\begin{array}{c}v \\
\left({ }^{\circ} \mathrm{C}\right)\end{array}$ & $\begin{array}{c}v \\
\left(\mathrm{~m}^{3} / \mathrm{kg}\right)\end{array}$ & $\begin{array}{c}h \\
(\mathrm{~kJ} / \mathrm{kg})\end{array}$ & $\begin{array}{c}S \\
(\mathrm{~kJ} / \mathrm{kg} . \mathrm{K})\end{array}$ \\
\hline 0 & 0.0009987 & 3.01 & 0.0000 \\
\hline$\ldots$ & $\ldots$ & $\ldots$ & $\ldots$ \\
\hline 300 & 0.081126 & 2992.4 & 6.5371 \\
\hline 350 & 0.090520 & 3114.4 & 6.7414 \\
\hline$\ldots$ & $\ldots$ & $\ldots$ & $\ldots$ \\
\hline 500 & 0.116174 & 3454.9 & 7.2314 \\
\hline 600 & 0.132427 & 3679.9 & 7.5051 \\
\hline
\end{tabular}

The data in Table 2 and table 3 are taken from properties of unsaturated water and superheated vapor (by pressure and temperature) in reference [3]. They show the properties of unsaturated water and superheated vapor at pressures of $3 \mathrm{MPa}$ and $10 \mathrm{MPa}$ respectively.

Table 3. Properties of unsaturated water and superheated vapor (by pressure and temperature)

\begin{tabular}{|c|c|c|c|}
\hline$p$ & \multicolumn{3}{|c|}{$10.0 \mathrm{MPa}$} \\
\hline \multirow{2}{*}{$\begin{array}{c}\text { Sat }=311.037^{\circ} \mathrm{C} \\
\text { properties }\end{array}$} & \multicolumn{3}{|c|}{$\begin{array}{c}\mathrm{v}^{\prime}=0.0014522 \mathrm{v}^{\prime \prime}=0.018000 \\
\mathrm{~h}^{\prime}=1407.2 \mathrm{~h}^{\prime \prime}=2724.5 \\
\mathrm{~s}^{\prime}=3.3591 \mathrm{~s}^{\prime \prime}=5.6139\end{array}$} \\
\hline \begin{tabular}{c}
$\left.{ }^{\circ} \mathrm{C}\right)$ \\
\hline 0
\end{tabular} & $\begin{array}{c}v \\
\left(\mathrm{~m}^{3} / \mathrm{kg}\right)\end{array}$ & $\begin{array}{c}h \\
(\mathrm{~kJ} / \mathrm{kg})\end{array}$ & $\begin{array}{c}S \\
(\mathrm{~kJ} / \mathrm{kg} . \mathrm{K})\end{array}$ \\
\hline$\ldots$ & 0.0009952 & 10.09 & 0.0004 \\
\hline 500 & 0.032750 & 3372.8 & 6.5954 \\
\hline 600 & 0.038297 & 3622.5 & 6.8992 \\
\hline
\end{tabular}

According to "properties of saturated water and vapor", the state parameters of wet steam can be determined. Table 4 shows some data of properties of saturated water and vapor by pressure. The data in Table 4 are taken from properties of saturated water and saturated vapor in reference [3].

Table 4. Properties of saturated water and vapor (by pressure)

\begin{tabular}{|c|c|c|c|c|c|c|c|}
\hline \multirow{2}{*}{ Press. } & \multirow{2}{*}{ Temp. } & \multicolumn{2}{|c|}{$\begin{array}{c}\text { Specific } \\
\text { volume }\end{array}$} & \multicolumn{2}{c|}{ Enthalpy } & \multicolumn{2}{c|}{ Entropy } \\
\cline { 3 - 8 } & $\begin{array}{c}\text { Sat. } \\
\text { liquid }\end{array}$ & $\begin{array}{c}\text { Sat. } \\
\text { vapor }\end{array}$ & $\begin{array}{c}\text { Sat. } \\
\text { liquid }\end{array}$ & $\begin{array}{c}\text { Sat. } \\
\text { vapor }\end{array}$ & $\begin{array}{c}\text { Sat. } \\
\text { liquid }\end{array}$ & $\begin{array}{c}\text { Sat. } \\
\text { vapor }\end{array}$ \\
\hline $\begin{array}{c}\mathrm{P} \\
\mathrm{MPa}\end{array}$ & $\begin{array}{c}\mathrm{t} \\
{ }^{\circ} \mathrm{C}\end{array}$ & $\begin{array}{c}v^{\prime} \\
\mathrm{m}^{3} / \mathrm{kg}\end{array}$ & $\begin{array}{c}v^{3} / \mathrm{kg} \\
\mathrm{m}\end{array}$ & $\begin{array}{c}h^{\prime} \\
\mathrm{kJ} / \mathrm{kg}\end{array}$ & $\begin{array}{c}h^{\prime \prime} \\
\mathrm{kJ} / \mathrm{kg}\end{array}$ & $\begin{array}{c}S^{\prime} \\
\mathrm{kJ} /(\mathrm{kg} . \mathrm{K})\end{array}$ & $\begin{array}{c}S^{\prime \prime} \\
\mathrm{kJ} /(\mathrm{kg} . \mathrm{K})\end{array}$ \\
\hline 0.001 & 6.9491 & 0.0010001 & 129.185 & 29.21 & 2513.29 & 0.1056 & 8.9735 \\
\hline$\ldots$ & & & & & & & \\
\hline 0.003 & 24.1142 & 0.0010028 & 45.666 & 101.07 & 2544.68 & 0.3546 & 8.5758 \\
\hline 0.004 & 28.9553 & 0.0010041 & 34.796 & 121.30 & 2553.45 & 0.4221 & 8.4725 \\
\hline 0.005 & 32.8793 & 0.0010053 & 28.191 & 137.72 & 2560.55 & 0.4761 & 8.3930 \\
\hline$\ldots$ & & & & & & & \\
\hline 2.064 & 373.99 & 0.003106 & 0.003106 & 2085.9 & 2085.9 & 4.4092 & 4.4092 \\
\hline
\end{tabular}

$$
\begin{aligned}
h_{1} & =3372.8+\frac{3622.5-3372.8}{600-500} \times(540-500) \\
& =3472.68 \quad \mathrm{~kJ} / \mathrm{kg} \\
h_{b} & =3454.9+\frac{3679.9-3454.9}{600-500} \times(540-500) \\
& =3544.9 \quad \mathrm{~kJ} / \mathrm{kg} \\
t_{s 2} & =28.9533 \quad{ }^{\circ} \mathrm{C}
\end{aligned}
$$




$$
\begin{aligned}
& h_{2}{ }^{\prime}=121.30 \quad \mathrm{~kJ} / \mathrm{kg} \\
& s_{1}=s_{a}=s_{A} \\
& =6.5954+\frac{6.8992-6.5954}{600-500} \times(540-500) \\
& =6.71692 \mathrm{~kJ} /(\mathrm{kg} \cdot \mathrm{K}) \\
& s_{a}=6.71692 \\
& =6.5371+\frac{6.7414-6.5371}{350-300} \times\left(t_{a}-300\right) \\
& t_{a}=(6.71692-6.5371) \times \frac{350-300}{6.7414-6.5371} \\
& =344 \quad{ }^{\circ} \mathrm{C} \\
& h_{a}=2992.4+\frac{3114.4-2992.4}{350-300} \times(344-300) \\
& =3099.76 \mathrm{~kJ} / \mathrm{kg} \\
& s_{A}=x_{A} s^{\prime \prime}+\left(1-x_{A}\right) s^{\prime} \\
& x_{A}=\frac{s_{A}-s^{\prime}}{s^{\prime \prime}-s^{\prime}} \\
& =\frac{6.71692-0.4221}{8.4752-0.4221}=0.782 \\
& h_{A}=x_{A} h^{\prime \prime}+\left(1-x_{A}\right) h^{\prime} \\
& =2553.45 \times 0.782+(1-0.782) \times 121.30 \\
& =2023.24 \mathrm{~kJ} / \mathrm{kg} \\
& s_{b}=s_{2} \\
& =7.2314+\frac{7.5051-7.2314}{600-500} \times(540-500) \\
& =7.34088 \mathrm{~kJ} /(\mathrm{kg} \cdot \mathrm{K}) \\
& s_{2}=x_{2} s^{\prime \prime}+\left(1-x_{2}\right) s^{\prime} \\
& x_{2}=\frac{s_{2}-s^{\prime}}{s^{\prime \prime}-s^{\prime}} \\
& =\frac{7.34088-0.4221}{8.4752-0.4221}=0.859 \\
& h_{2}=x_{2} h^{\prime \prime}+\left(1-x_{2}\right) h^{\prime} \\
& =0.859 \times 2553.45+(1-0.859) \times 121.30 \\
& =2176.3 \mathrm{~kJ} / \mathrm{kg} \\
& \eta_{t}=\frac{\left(h_{1}-h_{a}\right)+\left(h_{b}-h_{2}\right)}{\left(h_{1}-h_{2}^{\prime}\right)+\left(h_{b}-h_{a}\right)} \\
& =\frac{(3472.68-3099.76)+(3544.9-2176.3)}{(3472.68-121.30)+(3544.9-3099.76)} \\
& =45.87 \% \\
& d=\frac{3600}{\left(h_{1}-h_{a}\right)+\left(h_{b}-h_{2}\right)} \\
& =\frac{3600}{(3472.68-3099.76)+(3544.9-2176.3)} \\
& =2.07 \mathrm{~kg} /(\mathrm{kw} \cdot \mathrm{h})
\end{aligned}
$$

\section{Conclusion}

It can be seen from the calculation results:

After using the intermediate reheat, the exhaust dryness of the steam turbine can be improved, and the steam dryness in the low pressure cylinder can be kept within the normal working range. The adoption of reheat cycle will also affect the cycle thermal efficiency and steam consumption rate. Therefore, for reheat unit, the selection of reheat pressure is very important. If the reheat pressure is high, although the circle heat efficiency is improved, the steam does less work in the high pressure cylinder, so it has little effect on the whole cycle and the change of exhaust steam dryness is also small. If the reheat pressure is low, although the improvement of exhaust steam dryness is obvious, it may cause the decrease of circle heat efficiency. Therefore, considering the economy of the cycle, there must be an optimal reheat pressure range. As mentioned earlier, it is usually better to choose $20 \% \sim 30 \%$ of the initial reheat pressure. After adopting the reheat cycle, the work per kilogram of steam is increased, so the steam consumption rate is also reduced, thus reducing the burden of the water pump and condenser.

In this paper, through the calculation of examples, we further consolidate the theoretical knowledge and strengthen the importance of reheat pressure selection for reheat units. In addition, in the analysis of steam power cycle, not only h-s diagram but also thermodynamic property table of steam can be used.

Theoretically, with the increase of reheating times, the thermal efficiency will be higher. However, when the number of reheat is increased, the steam pipe and reheater are added, which makes the system complex, increases the investment cost, and brings inconvenience to the operation and maintenance. Therefore, reasonable selection of reheat times is also a comprehensive consideration of reheating units.

\section{References}

1. Zhao, L, Engineering Thermodynamics (A Bilingual Textbook) (2012), China Building Industry Press, Beijing.

2. Jing, Z.H. (2009) Thermal Engineering, China Electric Power Press, Beijing.

3. Xu, Y.P., Ke, X.Y. (2012) Thermal Engineering. ChinaElectricPowerPress, Beijing.

4. Zhou, J.H., Liu, X. (2010) Specialized English for thermal power generation, China Electric Power Press, Beijing

5. Hu, Y.H. (2008) Specialized English for thermal power generation, Tianjin University Press, Tianjin 